\title{
AN OPTIMAL INEQUALITIES CHAIN FOR BIVARIATE MEANS
}

\author{
ZHEN-HANG YANG AND YU-Ming CHU
}

\begin{abstract}
Let $p \in \mathbb{R}, M$ be a bivariate mean, and $M_{p}$ be defined by $M_{p}(a, b)=M^{1 / p}\left(a^{p}, b^{p}\right)$ $(p \neq 0)$ and $M_{0}(a, b)=\lim _{p \rightarrow 0} M_{p}(a, b)$. In this paper, we prove that the sharp inequalities $L_{2}(a, b)<P(a, b)<N S_{1 / 2}(a, b)<H e(a, b)<A_{2 / 3}(a, b)<I(a, b)<Z_{1 / 3}(a, b)<Y_{1 / 2}(a, b)$ hold for all $a, b>0$ with $a \neq b$, where $L(a, b)=(a-b) /(\log a-\log b), P(a, b)=(a-$ $b) /[2 \arcsin ((a-b) /(a+b))], N S(a, b)=(a-b) /[2 \operatorname{arcsinh}((a-b) /(a+b))], H e(a, b)=(a+$ $\sqrt{a b}+b) / 3, A(a, b)=(a+b) / 2, I(a, b)=1 / e\left(a^{a} / b^{b}\right)^{1 /(a-b)}, Z(a, b)=a^{a /(a+b)} b^{b /(a+b)}$ and $Y(a, b)=I(a, b) e^{1-a b / L^{2}(a, b)}$ are respectively the logarithmic, first Seiffert, Neuman-Sándor, Heronian, arithmetic, identric, power-exponential and exponential-geometric means of $a$ and $b$.
\end{abstract}

Mathematics subject classification (2010): 26E60.

Keywords and phrases: Logarithmic mean, first Seiffert mean, Neuman-Sándor mean, identric mean, power-exponential mean, exponential-geometric mean.

\section{REFERENCES}

[1] D. ACU, Some inequalities for certain means in two arguments, Gen. Math. 9, 1-2 (2001), 11-14.

[2] H. Alzer And W. Janous, Solution of problem 8*, Crux Math. 13 (1987), 173-178.

[3] P. S. Bullen, D. S. Mitrinović And P. M. VAsić, Means and Their Inequalities, D. Reidel, Dordrecht, 1988.

[4] Y.-M. ChU, M.-K. WANG AND Y.-F. QIU, An optimal double inequality between power-type Heron and Seiffert means, J. Inequal. Appl. 2010, Article ID 146945, 11 pages.

[5] Y.-M. Chu AND B.-Y. Long, Bounds of the Neuman-Sándor mean using power and identric means, Abstr. Appl. Anal. 2013, Article ID 832591, 6 pages.

[6] Y.-M. Chu, B.-Y. Long, W.-M. Gong AND Y.-Q. Song, Sharp bounds for Seiffert and NeumanSándor means in terms of generalized logarithmic means, J. Inequal. Appl. 2013, 10 (2013), 13 pages.

[7] I. Costin And G. TOADER, Optimal evaluations of some Seiffert-type means by power means, Appl. Math. Comput. 219, 9 (2013), 4745-4754.

[8] I. Costin And G. TOAdER, A nice separation of some Seiffert-type means by power means, Int. J. Math. Math. Sci. 2012, Article ID 430692, 6 pages.

[9] C. Gini, Di una formula comprensiva delle media, Metron 13, 2 (1938), 3-22.

[10] P. A. Ḧ̈sтö, A monotonicity property of ratios of symmetric homogeneous means, JIPAM. J. Inequal. Pure Appl. Math. 3, 5 (2002), Article 71, 23 pages.

[11] P. A. HÄstö, Optimal inequalities between Seiffert's mean and power mean, Math. Inequal. Appl. 7, 1 (2004), 47-53.

[12] A. A. JAGERS, Solution of problem 887, Nieuw Arch. Wisk. (4) 12 (1994), 230-231.

[13] G. JiA AND J.-D. CAO, A new upper bound of the logarithmic mean, JIPAM. J. Inequal. Pure Appl. Math. 4, 4 (2003), Article 80, 4 pages.

[14] T. P. LIN, The power mean and the logarithmic mean, Amer. Math. Monthly 81 (1974), 879-883.

[15] E. Neuman And J. SÁndor, On the Schwab-Borchardt mean II, Math. Pannon. 17, 1 (2006), 49-59.

[16] Z. PÁLES, Inequalities for sums of powers, J. Math. Anal. Appl. 131, 1 (1988), 265-270.

[17] A. O. PitTInger, Inequalities between arithmetic and logarithmic means, Univ. Beograd Publ. Elektrotehn. Fak. Ser. Mat. Fiz. 678-715 (1980), 15-18. 
[18] K. B. Stolarsky, The power and generalized logarithmic means, Amer. Math. Monthly 87, 7 (1980), 545-548.

[19] J. SÁndor, On certain inequalities for means III, Arch. Math. 76, 1 (2001), 34-40.

[20] J. SÁNDOR, A note on the Gini means, Gen. Math. 12, 4 (2004), 17-21.

[21] H.-J. SEIFFERT, Werte zwischen dem geometrischen und dem arithmetischen Mittel zweier Zahlen, Elem. Math. 42 (1987), 105-107.

[22] H.-J. SEIFFERT, Aufgabe $\beta$ 16, Die Wurzel 29 (1995), 221-222.

[23] S. ToAder, Derivatives of generalized means, Math. Inequal. Appl. 5 (2002), 517-532.

[24] ZH.-H. YANG, On the homogeneous functions with two parameters and its monotonicity, JIPAM. J. Inequal. Pure Appl. Math. 6, 4 (2005), Article 101, 11 pages.

[25] ZH.-H. YANG, On the log-convexity of two-parameter homogeneous functions, Math. Inequal. Appl. 10, 3 (2007), 499-516.

[26] ZH.-H. YANG, On the monotonicity and log-convexity of a four-parameter homogeneous mean, J. Inequal. Appl. 2008, Article ID 149286, 12 pages. 
[27] ZH.-H. YANG, Sharp bounds for the second Seiffert mean in terms of power means, arXiv: 1206.5494v1 [math. CA].

[28] ZH.-H. YANG, Sharp power means bounds for Neuman-Sándor mean, arXiv: 1208.0895v1 [math. $\mathrm{CA}]$.

[29] ZH.-H. YANG, Estimates for Neuman-Sándor mean by power means and their relative errors, J. Math. Inequal. 7, 4 (2013), 711-726. 